\title{
Genetic Transformation of Egg Shell Color in Chicken by the Use of Irradiated Sperm
}

\author{
Naoyuki Yамамото and Takeshi Tоміта \\ Laboratory of Animal Genetics, School of Agriculture, \\ Nagoya University, Furo-cho, Chikusa-ku, \\ Nagoya-shi, 464-01, Japan
}

\begin{abstract}
Genetic transformation of egg shell color has been attained in chickens by the use of gamma ray irradiated sperm. Double artificial inseminations were used. Recipient females were inseminated with irradiated semen from a donor strain with brown eggs and then 24 hours later with normal unirradiated semen from the recipient strain with white eggs. The frequency of transformation of egg shell color genes was $3.8 \%$ in the first progeny generation. Transferred genes were stable for at least four successive generations, and were integrated from generation to generation under selective mating. This technique may be useful for improving qualitative characters of the chicken strain in a relatively short time.
\end{abstract}

(Jpn. Poult. Sci., 29 : 213-220, 1992)

Key words : chicken, genetic transformation, gamma-ray irradiated sperm, egg shell color, pseudofertilization

\section{Introduction}

There are many reports on the production of transgenic mammals by microinjection of foreign DNA into the male pronucleus of fertilized ova (BRINSTER et al. 1985, HAMmER et al. 1985, WAGNER et al. 1981). Other techniques such as the use of retroviral vector (RUBENSTEIN et al. 1986) and electroporation (PotTER et al. 1984) are also used. To date reports on transgenic poultry are scanty, despite the feasibility and potential economic importance of the technology (CRITTENDEN and SALTER 1985, Freeman and MESSER 1985, WAGNer 1985). Attempts to alter the chicken germline by gene transfer into follicles or in vitro cultured early embryos have not been successful (Shuman and SHOFFner 1986). In order to produce transgenic chickens a novel method of gene transfer should be developed.

PANDEY and PATCHell (1982) have attained genetic transformation of egg shell and feather color in chickens by the use of heavily $\gamma$-ray irradiated sperm. They showed that genes coding for egg shell or feather color could be transferred in a frequency of $3.5 \%$ to the progeny through irradiated spermatozoa. The present studies have been conducted to verify the "genetic transformation technique" as described by them in order to develop a highly productive brown egg strain.

\section{Materials and Methods}

Two strains of chickens were used. A White Leghorn G strain (WL-G) which has

Received Dec. 27, 1991 
white feathers, pure white eggs and high egg production was used as the recipient. A strain of Rhode Island Red Y 8 birds (RIR-Y 8) which has brown feathers and brown eggs was served as donors.

Semen was collected from RIR-Y 8 and WL-G males by abdominal massage (Bogdonoff and Shaffner 1954). Semen samples were diluted three-fold with Ringer solution.

Sperm motility, Sperm survival rate and semen $\mathrm{pH}$ were examined. Sperm motility and survival rate were estimated microscopically by eye. Sperm motility score was indicated as follows : very high $(+++)$, high $(++)$, medium $\left(^{+}\right)$and low $( \pm)$. Sperm survival rate was given as the ratio of the number of dead sperm over the total sperm counts. Semen $\mathrm{pH}$ was checked by $\mathrm{pH}$ paper.

Pooled semen collected from the RIR-Y 8 males was divided into two parts. One part was kept at room temperature while the other part was irradiated by $\boldsymbol{\gamma}$-ray of ${ }^{60}$ Co source (Cobalt 60 Gamma Ray Irradiation System, Faculty of Engineering, Nagoya University). Irradiation was done at 370, 770 and 1160 Gy at room temperature for 20 to 60 minutes at a distance $10 \sim 15 \mathrm{~cm}$ from the source of irradiation. WL $-\mathrm{G}$ females were first inseminated with the irradiated semen. The next day (about 24 hours later), they were further inseminated with freshly collected unirradiated WL-G semen.

The dose of inseminations was $0.2 \mathrm{~m} l$ per female for irradiated or unirradiated semen. Two days after insemination, eggs laid were collected for two weeks and kept at $12^{\circ} \mathrm{C}$ until incubation.

Incubation was carried out at $37.8^{\circ} \mathrm{C}$ for 21 days under relative humidity of $60 \sim 80 \%$. Newly hatched chicks were checked for sex and plumage color. All chickens were fed a standard commercial layer diet (Chick-food for up to $0 \sim 2$ weeks, Chusu for $2 \sim 6$ weeks, Daisu for 6 weeks $\sim$ maturity and L-mash after maturity, each diet is shown after registered name of manufacturer, Nihon Nosan Kogyo and Co., Ltd. and water was given ad libitum.

Photometric measurements of egg shell color were carried out with a reflection photo difference meter (Tokyo Denshoku \& Co., Ltd, TC-1500 MC) (brightness : L value, red component : a value and yellow component : $b$ value) at the blunt end of the egg. These three values of strains and generations were examined statistically. For the synthetic estimates of egg shell color, $Z$ values were calculated for each egg by a discriminate function formula using three color values. The formula used was $Z=a_{1}$ $\left(\mathrm{x}_{1}-\overline{\mathrm{x}}_{1}\right)+\mathrm{a}_{2}\left(\mathrm{x}_{2}-\overline{\mathrm{x}}_{2}\right)+\mathrm{a}_{3}\left(\mathrm{x}_{3}-\overline{\mathrm{x}}_{3}\right)$, where $\mathrm{a}_{1}=0.0429053, \mathrm{a}_{2}=0.162609, \mathrm{a}_{3}=0.166231$, $\mathrm{x}_{1}=\mathrm{L}$ value, $\mathrm{x}_{2}=\mathrm{a}$ value and $\mathrm{x}_{3}=\mathrm{b}$ value, respectively.

Each generation from the second to the fourth of genetic transformation chickens was produced as follows : the second generation was produced by mating of random selected males and selected females laid brownish colored eggs. The third generation was produced by mating of selected males whose mother hens laid the colored eggs and the selected females laid the colored eggs. The fourth generation was produced exactly by the same way as that of the third generation. 


\section{Results}

Irradiation adversely affected sperm survival rates with levels of irradiation (Table 1). Motility of surviving sperm was slightly reduced after irradiation at all doses of irradiation. Semen $\mathrm{pH}$ increased in all irradiation groups (Table 1).

When the WL-G hens were inseminated with only the irradiated semen of RIR-Y 8 , no fertilized eggs were obtained regardless of the intensity of irradiation.

In an attempt to make transgenic chickens: we decided to use the semen irradiated by $770 \mathrm{~Gy}$. The first and subsequent generittions of the transgenic chickens were designated as WL $-r 1, \mathrm{WL}-r 2$, WL $-r$, etc.

The 77 WL-G females laid a total of 956 eggs in two weeks. The number of chicks (WL $-r$ 1) hatched was 714 (hatchability 75\%, 378 males, 336 females). There were no differences in the rate of malformation and feathering between WL- $r 1$ and control WL $-\mathrm{G}$ chicks. Among the WL- $r 1$ female chicks, 312 out of 336 survived until 180 days of age. Of the $312 \mathrm{WL}-r 1$ females which started laying, $12(3.8 \%)$ laid brownish colored shell eggs.

Egg production performances (egg weight at 240 days of age, body weight at 240 days of age and egg laying rate during $151 \sim 270$ days of age) of WL $-r 1$ females were almost the same as those of the original WL-G females (Table 2).

The genetic transmittance of the colored egg shell gene(s) was examined by successive selective matings to the females with brownish egg shell color. Number of

Table 1. Effects of $\gamma$-ray irradiation on sperm motility, sperm survival rate and semen $\mathrm{pH}$ of RIR-Y 8

\begin{tabular}{cccc}
\hline $\begin{array}{c}\text { Irradiation } \\
\text { dose (Gy) }\end{array}$ & $\begin{array}{c}\text { Sperm } \\
\text { motility }\end{array}$ & $\begin{array}{c}\text { Sperm survival } \\
\text { rate }(\%)\end{array}$ & $\begin{array}{c}\text { Semen } \\
\mathrm{pH}\end{array}$ \\
\hline 0 & $+^{\mathrm{a}}$ & $80 \sim 90$ & $6.6 \sim 6.8$ \\
370 & + & $60 \sim 70$ & 7.2 \\
770 & + & $30 \sim 40$ & 7.6 \\
1160 & \pm & 0 & 7.2 \\
\hline a "+" and " \pm " indicate medium and low motility, \\
respectively.
\end{tabular}

Table 2. Egg production performances of WL-r 1 and WL-G

\begin{tabular}{lcccc}
\hline Strain & $\begin{array}{c}\text { No. of } \\
\text { females }\end{array}$ & $\begin{array}{c}\text { Egg weight } \\
\text { at } \\
240 \text { days (g) }\end{array}$ & $\begin{array}{c}\text { Body weight } \\
\text { at } \\
240 \text { days (g) }\end{array}$ & $\begin{array}{c}\text { Egg production } \\
\text { rate at } \\
151 \sim 270 \text { days } \\
(\%)\end{array}$ \\
\hline WL-r 1 & 26 & $56.8 \pm 4.0^{\mathbf{a}}$ & $1635 \pm 151$ & $89.4 \pm 8.7$ \\
WL-G & 288 & $56.4 \pm 4.2$ & $1614 \pm 147$ & $90.6 \pm 9.5$ \\
WL-G ${ }^{\text {b }}$ & & 56.8 & 1681 & 89.7 \\
\hline
\end{tabular}

a : Mean \pm S.D.

b : Average of 4 years 
females laid colored shell eggs was $12 / 312(3.8 \%)$ in WL $-r 1,8 / 297(2.7 \%)$ in WL $-r 2$, $8 / 74(10.8 \%)$ in WL $-r 3$, and $19 / 62(30.6 \%)$ in WL $-r 4$, respectively.

Photometric variations of egg shell color ( $\mathrm{L}$ value, a value and $\mathrm{b}$ value) in RIR-Y 8, WL-G and their hybrids were measured (Table 3). Brightness (L value) of RIR-Y 8 eggs were remarkably low as compared with that of WL-G eggs. Red (a value) and yellow (b value) components in RIR-Y 8 were high compared with those in WL-G. Three color values between strains were significant $(\mathrm{P}<0.01)$. Table 4 shows photometric values of egg shell color from WL $-r 1$ to WL $-r 4$. L value of WL $-r 4$ was almost seven points lower than that of WL-r 1 . The a value was negative in all generations. The b value was increased in WLr 4 compared with that in WL- $r$. All three color values of WL- $r 4$ showed the best points among the successive four generations, but still do not reach to the parental strain RIR-Y 8 and (RIR-Y $8 \times$ WL-G) $F_{1}$. Egg shell color values between $W L-r 1$ and $W L-r 4$ were statistically

Table 3. Photometric values of egg shell color of RIR-Y 8, WL-G and $F_{1}$

\begin{tabular}{lcccc}
\hline \hline Strain & $\begin{array}{c}\text { No. of } \\
\text { eggs }\end{array}$ & $\begin{array}{c}\text { L-value } \\
\text { (brightness) }\end{array}$ & $\begin{array}{c}\text { a-value } \\
\text { (red component) }\end{array}$ & $\begin{array}{c}\text { b-value } \\
\text { (yellow } \\
\text { component) }\end{array}$ \\
\hline RIR-Y 8 & 147 & $61.48 \pm 3.30^{*, a}$ & $5.26 \pm 0.78^{\mathrm{a}}$ & $18.94 \pm 1.10^{\mathrm{a}}$ \\
(RIR-Y 8 $\times$ WL-G) F $F_{1}$ & 243 & $76.60 \pm 4.00^{\mathrm{b}}$ & $1.59 \pm 1.61^{\mathrm{b}}$ & $16.10 \pm 2.19^{\mathrm{b}}$ \\
WL-G & 549 & $87.88 \pm 1.04^{\mathrm{c}}$ & $-1.56 \pm 0.30^{\mathrm{c}}$ & $5.23 \pm 1.83^{\mathrm{c}}$ \\
\hline
\end{tabular}

*: Mean \pm S.D.

a,b,c : Values with different superscripts differ significantly at $\mathrm{P}<0.01$

Table 4. Photometric values of egg shell color of transgenic chickens in successive generations (WL-r 1, r 2, r3 and $r 4$ )

\begin{tabular}{ccccc}
\hline Generation & $\begin{array}{c}\text { No. of } \\
\text { eggs }\end{array}$ & $\begin{array}{c}\text { L-value } \\
\text { (brightness) }\end{array}$ & $\begin{array}{c}\text { a-value } \\
\text { (red component) }\end{array}$ & $\begin{array}{c}\text { b-value } \\
\text { (yellow component) }\end{array}$ \\
\hline WL-r 1 & 60 & $85.65 \pm 5.47^{*, \mathrm{a}}$ & $-2.15 \pm 0.51^{\mathrm{a}}$ & $12.26 \pm 1.33^{\mathrm{a}}$ \\
WL-r 2 & 40 & $82.77 \pm 3.46$ & $-1.91 \pm 0.61^{\mathrm{b}}$ & $12.20 \pm 1.77$ \\
WL-r 3 & 40 & $82.85 \pm 0.76$ & $-1.68 \pm 0.24^{\mathrm{c}}$ & $10.80 \pm 0.91^{\mathrm{b}}$ \\
WL-r 4 & 95 & $78.75 \pm 2.52^{\mathrm{b}}$ & $-1.03 \pm 0.78^{\mathrm{d}}$ & $13.31 \pm 2.16^{\mathrm{c}}$ \\
\hline
\end{tabular}

*: MeantS.D.

a.b,c,d : Values with different superscripts differ significantly at $\mathrm{P}<0.01$.

Table 5. Photometric values of egg shell color of (RIR-Y $8 \times W L-G) F_{1}$ and (RIR$\mathrm{Y} 8 \times \mathrm{WL}-r$ 2) $\mathrm{F}_{1}$

\begin{tabular}{ccccc}
\hline $\begin{array}{c}\text { Mate } \\
\text { male } \times \text { female }\end{array}$ & $\begin{array}{c}\text { No. of } \\
\text { eggs }\end{array}$ & $\begin{array}{c}\text { L-value } \\
\text { (brightness) }\end{array}$ & $\begin{array}{c}\text { a-value } \\
\text { (red component) }\end{array}$ & $\begin{array}{c}\text { b-value } \\
\text { (yellow } \\
\text { component) }\end{array}$ \\
\hline (RIR-Y 8 $\times$ WL-G) $F_{1}$ & 244 & $76.60 \pm 4.00^{\mathrm{a}}$ & $1.59 \pm 1.61^{\mathrm{a}}$ & $16.10 \pm 2.19$ \\
$\left(\mathrm{RIR}-\mathrm{Y} 8 \times\right.$ WL-r 2) $\mathrm{F}_{1}$ & 42 & $69.91 \pm 4.12^{\mathrm{b}}$ & $2.59 \pm 1.83^{\mathrm{b}}$ & $16.39 \pm 1.95$ \\
\hline
\end{tabular}

a,b : Values with different superscripts differ significantly at $\mathrm{P}<0.01$. 
significant $(\mathrm{P}<0.01)$. Compared with three values of egg shell color between (RIR$\mathrm{Y} 8 \times \mathrm{WL}-\mathrm{G}) \mathrm{F}_{1}$ and $(\mathrm{RIR}-\mathrm{Y} 8 \times \mathrm{WL}-r 2) \mathrm{F}_{1}$ the differences of $\mathrm{L}$ and a value were significant $(\mathrm{P}<0.01) \quad$ (Table 5). Discriminate functions were calculated after $\mathrm{Z}$ transformation using the three values of egg shell color in the successive four generations. The $Z$ value of one $W L-r 4$ female exceeded the mean $Z$ value of $F_{1}$ $(\mathrm{WL}-\mathrm{G} \times \mathrm{RIR}-\mathrm{Y} 8)$.

\section{Discussion}

Results of our experiments have clearly shown the success of gentic transformation in the chicken based on the technique described by PANDEY and PATchell (1982). The frequency of genetic transformation in this study was $3.8 \%$ in WL-r 1 . This frequency was almost the same as that of PANDEY's (3.5\%). BAUMGARTNER et al. (1986) reported a much lower frequency in his study in which 3,646 potential transformation events were screened, and only one apparent transformation has occurred $(0.027 \%)$. The different frequencies of genetic transformation might be associated with the difference of the chicken strain combinations used. BUMSTEAD et al. $(1987 \mathrm{a}, \mathrm{b})$ reported that genetic material from irradiated semen was incorporated into the embryo and expressed, but transferred rate was low and cellular mechanism of expression was not clear. SHOFFner et al. (1990) reported that chromatin fragments derived from irradiated spermatozoa was not viable vectors for gene transfer.

Kosin (1944), SARvella (1971) and PANDEy (1980) found that the motility of sperm was significantly decreased as irradiation doses increased from 85 or 100 to $250 \mathrm{~Gy}$. In this paper, we examined the influence of irradiation on chicken semen. The results showed that $1,160 \mathrm{~Gy}$ of radiation caused complete destruction of sperm motility. It was possible to recover motility of sperm by $50 \%$ by 770 Gy irradiation. Sperm survival rate was decreased greatly after irradiation, and DNA strands in the sperm might be fragmented by these high irradiation doses.

It was observed that semen $\mathrm{pH}$ was increased by all doses of irradiation. Generally, motility of sperm was not affected until the $\mathrm{pH}$ value was close to 8.5. The $\mathrm{pH}$ increase observed in this study should have no effect on sperm motility.

No embryos developed in eggs from females inseminated with only irradiated sperm which had received 370,770 and $1160 \mathrm{~Gy}$. These results agreed with the previous result of Kosin (1944).

It was suggested that ionising radiation effectively destroyed sperm fertile ability. On the basis of the results, we decided the irradiation dose of 770 Gy for attaining successful genetic transformation in chicken while avoiding possible fertilization by irradiated sperm.

Usually, sperms penetrate the egg through the vitelline membrane. Then fertilization occurs, and embryos develop normally. On the other hand, irradiated sperm may penetrate the egg, but fertilization does not take place. There are also ample evidene from observations on a variety of animals that sperm treated with relatively high doses of irradiation sufficient for DNA pulverization may maintain their motility and 
may be capable of pseudofertilization (HERTwig 1911). Therefore, if pseudofertilized egg are capable of undergoing a second insemination, it might be possible to use the egg transformation technique in animals including avian species. Production of transgenic chickens seems to require the second insemination with normal unirradiated semen after the first insemination with irradiated semen. It is suggested that the unirradiated sperm penetrated and fertilized the egg.

In this technique integrations of the host DNA should be random. Therefore it is possible that the hatched chicks could have received many genes from RIR-Y 8 . However, no chicks showed transmission of other genes from donor sperm than egg shell color in our experiments. We can rule out the possibility of getting a $F_{1}$ hybrid in the WL- $r$ generation because we could not observe any change within the limits of plumage color and other outside form in WL- $r$.

In the WL- 1 generation, 12 of 312 females (3.8\%) laid brownish colored eggs. There was no evidence of any color other than white for egg or feather colors in the WL-G. Therefore it is suggested that the brownish color of the egg shell in WL- $r 1$ could have derived only from the $\gamma$-ray irradiated sperm of RIR-Y 8 .

Production of transgenic chicken using $\gamma$-ray irradiated sperm has some disadvantages ; incorporation of the host DNA is random, and irradiation of semen requires expensive facilities. But more than 200 progeny can be obtained per year and hen in layer chickens. When transgene related to egg shell color of WL $r 1$ is transmitted from generation to generation, it is possible to establish a transgenic chicken strain. In our experiment, from WL-r 1 to $\mathrm{WL}-r 4$, the transgene related to egg shell color of RIR-Y 8 has been transmitted steadily and even increasingly.

The egg shell color is determined by a number of genes. It is known that brown color is dominant over white (McDonald 1959, Hunton 1962). Not all egg shell color genes were transmitted to the individual transgenic chick. But we can integrate these genes by selective matings in the following generations. Actually, WL $-r 4$ laid the most brownish colored shell eggs among the all successive generations.

In this studies, only egg shell color genes were available to prove gene transformation of RIR-Y 8 genomes to WL-G. It is possible that some genes other than egg shell color genes were integrated simultaneously.

The present results showed that genetic transformation using $\gamma$-ray irradiated sperm is possible in chicken. Using this technique new chicken strains can be established by introducing useful genes. Disease resistance genes can also be introduced without changing genetic peculiarities of a strain. Moreover, new information may be obtainable concerning the mechanisms of fertilization, and integration and expression of foreign genes in the host genetic background.

\section{Acknowledgements}

The authors wish to thank K. Otsuka, M. Oнta and K. Hirose of Aichi-ken Agricultural Research Center for their help to these studies.

We are also grateful to Dr. Charles P.W. TSANG of Centre for Food and Animal Research, Agriculture Canada, who kindly read this manuscript. 


\section{References}

Baumgartner, J., I.E. Ezzat and Z. Koncecova (1986) An attempt at genetic transformation in chickens through cock sperm irradiation. Theoretical and Applied Genetics, 72 : 264-268.

Bogdonoff, P.D. and C.S. Shaffner (1954) The effect of $\mathrm{pH}$ on in vitro survival, metabolic activity and fertilizing capacity of chicken semen. Poultry Science, 33 : $665-669$.

Brinster, R.L., H.Y. Chen, M.E. Trumbauer, M.K. Yagle and R.D. Palmiter (1985) Factors affecting the efficiency of introducing foreign DNA into mice by microinjecting eggs. Proceedings of the National Academy of Science. USA, 82 : 4438-4442.

Bumstead, N., L.I. Messer, B.M. Freeman and A.C.C. Manning (1987 a) Genetic transformation of chickens using irradiated male gametes. Heredity, 58:25-30.

Bumstead, N., B.M. Freeman, A.C.C. Manning and K. Howes (1987 b) Genetic transformation of chickens using irradiated sperm : co-transfer of undesirable genes. Avian Pathology, 16 : 417-424.

CRittenden, L.B. and D.W. Salter (1985) Genetic engineering to improve resistance to viral diseases of poultry: a model for application to livestock improvement. Canadian Journal of Animal Science, 65: 553-562.

Freeman, B.M. and L.I. Messer (1985) Genetic manipulation of the domestic fowl-a review. World's Poultry Science Journal, 41 : 124-132.

Hammer, R.E., V.G. Pursel, C.E. Rexroad Jr, R.J. Wall, D.J. Bolt, K.M. Ebert, R.D. PALmiter and R.L. Brinster (1985) Production of transgenic rabbits, sheep and pigs by microinjection. Nature, $315: 680-683$.

HeRTwig, O. (1911) Die Radiumkrankheit tierischer Keimzellen. Archiv für mikroskopische Anatomie und Entwicklungsmechanik, 77 : 1-154.

Hunton, P. (1962) Genetics of egg shell colour in light Sussex flock. British Poultry Science, $3: 189-193$.

Kosin, I.I. (1944) Some aspects of the biological action of X-rays on cock spermatozoa. Physiological Zoology, 17 : 289-319.

McDonald, M.W. (1959) Progeny testing for dominant white in meat type chickens. Poultry Notes, Department of Agriculture, New South Wales, Austraria, October: 1-5.

PANDEY, K.K. (1980) Parthenogenetic diploidy and egg transformation induced by irradiated pollen in Nicotiana. New Zealand Journal of Botany, 18: 203-207.

PANDEY, K.K. and M.R. PATChell (1982) Genetic transformation in chicken by the use of irradiated male gametes. Molecular and General Genetics, 186 : 305-308.

Potter, H., L. Weir and P. Leder (1984) Enhancer-dependent expression of human $k$ immunoglobuline genes introduced into mouse pre-B lymphocytes by electroporation. Proceedings of the National Academy of Science. USA, 81 : 7161-7165.

Rubenstein, J.L.R., J-F. NicOlas and F. JACOB (1986) Introduction of genes into preimplantation mouse embryos by use of a defective recombinant retrovirus. Proceedings of the National Academy of Science. USA, $83: 366-368$.

SARvella, P. (1971) Frequency of parthenogenesis in chickens after insemination with irradiated sperm. Radiation Research, 46:186-191.

Shoffner, R.N., J.S. Otis, L.A. SNyder and K.S. Guise (1990) The improbability of irradiated spermatozoa as gene transfer vectors in chickens. Theoretical and Applied Genetics. $80: 228-233$.

Shuman, R.M. and R.N. Shoffner (1986) Symposium: molecular approaches to poultry breeding, Gene transfer by avian retroviruses. Poultry Science, 65 : 1437-1444.

Wagner, T.E., P.C. Hoppe, J.D. Jollick, D.R. Scholl, R.L. Hodinka and J.B. Gault (1981) Microinjection of a rabbit $B$-globin gene into zygotes and its subsequent expression in adult mice and their offspring. Proceedings of the National 
Academy of Science. USA, $78: 6378-6380$.

WAGNER, T.E. (1985) The role of gene transfer in animal agriculture and biotechnology.

Canadian Journal of Animal Science, 65 : 539-552.

\title{
ガンマー線照射精子による遺伝子導入ニワトリの卵殼色
}

\author{
山本直幸・富田 武 \\ 名古屋大学農学部家畜育種学教室 $\mathbf{T} 464-01$ 愛知県名古屋市千種区不老町
}

\begin{abstract}
本研究は, ニワトリにおいてガンマー線を照射したド ナー系統の精子を用いて，レシピエント系統へドナー系 統があつ卵款色遺伝子の導入を試みた。まず,ドナー系 統であるロードアイランドレッド種 Y 8 系 (RIR-Y 8) の精子にコバルト 60 を線源とするガンマー線 $770 \mathrm{~Gy}$ を照射し，レシピエント系統のホワイトレグホーン種 $\mathrm{G}$ 系（WL-G）の雌に人工授精した。次いで 24 時間後, WL-G の非照射正常精子を人工授精した。

その結果, 77 羽の WL-G 雌より合計 956 個の卵が 得られ，その内の 714 個が粰化（粰化率 $75 \%$, 雄 378 羽, 雌 336 羽) した。穏化した煼を遺伝子導入系第 1 世 代（WL-r 1）とした。産卵を開始したWL- $r 1$ 雌 312 羽の内で 12 羽（3.8\%）が着色卵を産卵した。WL-r 1 の産卵性能は WL-G との比較においても差はなかった。 この第 1 世代以降は選択交配を行い次世代を作出した結 果，着色卵を産卵した個体は WL $-r 2$ で 8/297 (2.7\%), WL-r 3 で 8/74 (10.8\%), WL-r 4 で 19/62 (30.6\%) であった。卵殼色の測定には測色色差計を用い，L値 (明るさ), a 值 (赤色), b 值（黄色）の 3 成分を測定
\end{abstract}

した。WL-r 4 における卵殼色の平均値は他の世代に 比較して, より着色程度が高いものであった。WL-G 系統においてはこれまで着色卵の産卵は確認されていな く，また，WL-r 1 ではホワイトレグホーン種よロード アイランドレッド種との $\mathrm{F}_{1}$ で見られるような羽毛形質 は確認されなかった。これらのことから，WL $-r$ 系で の卵款色形質は RIR-Y 8 の照射精子由来である可能性 を示唆するものであると考えられる。

本研究で用いた遺伝導入技術は, 目的とする遺伝子の みの導入が困難であるために，形質の発現をもとに選択 交配をおこなっていく必要がある。しかしながら，ニワ トリの高い繁殖性を利用することで，比較的短期間で特 定の質的遺伝子の導入を目的とした育種改良が行える可 能性を持つあのである。今後, ドナー照射精子由来 DNA の確認などが望まれる。

（家禽会誌，29：213～220,1992） キーワード : ニワトリ, 遺伝子導入, ガンマー線照射精 子, 卵款色, 偽受精 